\title{
Perspectives of Social Work in the Area of Intervention and Elimination of Domestic Violence against Children
}

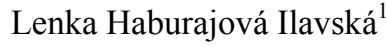 \\ ${ }^{1}$ Tomas Bata University in Zlín, Zlín, Czech \\ Correspondence: Lenka Haburajová Ilavská, Faculty of Humanities, Tomas Bata University in Zlín, nám. T. G. \\ Masaryka 5555, 76001 Zlín, Czech. E-mail: haburajova@fhs.utb.cz
}

Received: August 21, 2013

doi:10.5539/ass.v10n2p47
Accepted: September 23, 2013 Online Published: December 29, 2013

URL: http://dx.doi.org/10.5539/ass.v10n2p47

\begin{abstract}
In this article we describe some stages of social work, and we specify them in regard to children experiencing domestic violence. Consequently we present research results, which was concentrated to determine specific operating processes and methods of social work with children experiencing domestic violence.
\end{abstract}

Keywords: social work, domestic violence, methods of social work, detection, diagnostics, social intervention, therapy

\section{Introduction}

The origin of violence can be dated back to the beginning of human society. We constantly meet with different forms of violence; mostly as uninvolved, sometimes as potential victims, perpetrators or witnesses of violence. We should denounce any violence with which we meet from different perspectives.

Violence and wickedness were tolerated in the past as a natural part of life. Violence on children was deliberately suppressed in our country in order to create an illusion that this problem does not exist. Nowadays the fact of existence of violence on children is tangible. However, what we have changed is a sensibility with which this kind of violence is differentiated. Perspectives and focus on an issue of violence on children have changed in recent years; they have become a part of a fight for humanity, tolerance and non-violence. In recent years, corporal punishments, even punishments as such, have started to be refused. In general it can be stated that the violence is one of expression of wickedness. Violence is the most often used designation of unrepeated physical act or a practice when one man inflicts injury of the other person (Ondrejkovič, 2000, p. 27).

In a wider sense, the domestic violence also presents psychological or other (social, economic, ...) violence, such as repeated verbal attacks, swearing, harassment, and humiliation. In simply words, domestic violence can be understood as violence at home or within a family which assumes close relationships between a victim and an abuser, while it may include signs of sexual or physical violence, as well as psychological or social torture and neglect.

Repeated violence that is characterized by a cruelty, degrading approach causing serious physical and mental endangering can be denominated as an abuse. A term CAN (Child Abuse and Neglect) syndrome is used for an entire complex of abuse, its expressions and consequences. Since 1992 this term has included: physical abuse, sexual abuse, emotional abuse, neglect, and system abuse-secondary humiliation.

Violence on women and within the family presents violation of human rights. The Slovak Republic accepts all important international documents dealing with human rights. The Slovak Republic ratified many of them during the existence of the Czechoslovakia. After separation in 1993, the Slovak Republic became a contractual party by the succession. They were particularly the following documents: International Convention on the Elimination of all Forms of Racial Discrimination (No. 95/1974 Coll.), International Covenant on Economic, Social and Cultural Rights (No. 120/1976 Coll.), International Covenant on Civil and Political Rights (No. 120/1976 Coll.), Convention against Torture and other Cruel, Inhuman, or Degrading Treatment and Punishment (No. 143/1988 Coll.), Convention on Rights of the Child (No. 104/1991 Coll.), Convention on Political Rights of Women (No. 46/1955), Convention on the Elimination of all Forms of Discrimination against Women (No. 62/1987 Coll.), Option Protocol to the International Covenant on Civil and Political Rights (No. 169/1991 Coll.), Option Protocol to UN Convention on Elimination of all Forms of Discrimination against Women (No. 343/2001 Coll.). 
The government delegations of the Slovak Republic have attended international conferences on human rights organized by the United Nations and Council of Europe since 1993, where several action platforms and declarations were adopted. The Slovak Republic has assumed a political obligation to enforce recommendations of these conferences within its internal policy, including measures focused on elimination of all forms of violence and combating of human rights.

In order to meet adopted international obligations related to the human rights and to prevent abuse of the human rights, the Slovak Republic has adopted several documents dealing with specific living conditions of women, children, elderly people and disabled people. These documents also contain measures focused on elimination of violence on women and in families at different stages of progress.

Nowadays, the most complex in-process issue is an issue of violence committed on children. Particular measures to ensure rights of the children and prevention of socio-pathological phenomena, including prevention of violence in families, torture and abuse of children are included in the "National Action Plan for Children" (hereinafter referred to as "NAPD" adopted by the SR Government Resolution No. 837/2002). NAPD sets tasks of individual departments. A special attention is particularly paid to children who need protection against any form of physical or psychological violence, neglect, abuse or exploitation. Tasks and measures in the field of violence against children are defined particularly in the parts Protection of children and youth against negative phenomena, Child care and family care and care for children who are not raised in their own families, Education of employees from different fields (individual departments), who work with children and for children, methodology, etc.

There are several theoretical attitudes that explain reasons of domestic violence from various perspectives. In simple words, according to Erdélyová (2001), some theories concentrate on individual and search for personal explanations of violence, such as alcohol, drugs, mental illness, or violence in primary family. Other experts refuse personal and individual theory and claim that the violence is based on social (segregation of men and women) and structural theories (traditions, values, customs).

Possible causes of violence are described by Dutton (Č́rtková, 2006) in multi-causal concept of violence:

1) macro-system causes-a society is hierarchical with leading role of a man, on which excuse and undervalue of violence may be based;

(violence belittlement is by centuries proven practice in the society, when a woman-a victim was blamed for an undesirable phenomenon of violence in a cohabitation of a man and a woman; a woman was understood as a starter of aggressor's attack-e.g. his dissatisfaction with management of household, quality of food, upbringing of children)

2) Exo-system causes-environment, surrounding of the individual, and social structure may influence violent behavior in family, e.g. low income, unemployment;

3) micro-system causes of violence-these are families with the situations and circumstances which increase tendency to domestic violence (prescribed roles, individual characteristic of a victim and abuser, etc.)

The theory of these models are specified violence and neglect within the family:

1) Walker's model of cyclic violence consists of three phases. The first phase is about initiation of tension-an abuser is critical, he/she aggresses and abases a victim, and he/she believes in his/her right to behave violently. The second phase is critical-here, the abuser commits violence without a cause or by irrational thinking; he/she looses control and is aggressive. The third phase is a phase of peace-the abuser feels sorry for his/her behavior, he/she is careful and kind. The victim lives in illusion that the abuser has changed and therefore, the victim refuses help.

2) Model of violence from the perspective of the theory of aggressiveness-from the psychological perspective, the following factors participate on acts of violence: Aggressiveness (a disposition to react in an aggressive manner), aggressive behavior, aggression (demonstration of aggressiveness), hostility (unfriendly behavior), violence (conscious demonstration of aggression). Aggression is understood by the authors differently. It may be caused by external stimuli, biological factors (level of testosterone), alcohol, or by learned answer-social learning theory.

3) Ecological model explains violence as an interaction of several factors that are interconnected. It understands the violence as a complex problem caused by biological (income, age, personality disorder), social (relations within the family and outside the family, upbringing), cultural (relations at school, at work), economical and political factors (economy, standards, rights and obligations, social policy). 
4) Social interaction model-it concentrates on interaction between a parent and a child-theory of binding in context of wider social environment.

5) Social learning theory-violence is learned social behavior and aggression is learned answer. Strengthening, rewarding and punishment for imitation of behavior are important.

6) Theory of learned helplessness-it is an experience of a man with unpleasant situation he/she could not affect in the past. Therefore, he/she becomes apathic against the similar situations; he/she feels helpless and so passively undergoes violence.

According to Seligman concept of learned helplessness, a victim is surprised in the initial phase, he/she neutralizes the situation by different mechanisms, e.g. by excusing of abuser's behavior (it is my fault, etc.). The next phase is a phase of inability to control behavior of the abuser, what finally results in loss of activity and motivation to search for a solution of the violence (Č́rtková, 2006).

Nowadays, multi-factor approach is dominant. It connects separate approaches and creates a description of domestic violence as a complicated and complexly conditioned phenomenon (Čírtková, 2006).

It is necessary to pay attention on the following issues in prevention of violence:

1) identification of individual risk factors and implementation of intervention measures modifying risk behavior of an individual;

2) formation of a healthy family environment by influencing a close relationship between a person and work; provision of a professional help and support to dysfunctional families;

3) monitoring of public places such as schools, workplaces, nursery schools and solving of problems that may lead to violence;

4) influencing of gender stereotypes, cultural values and practices forming a source of violence;

5) identification of broad cultural, social and economic factors that support violence and implementation of such steps that would change these factors.

\subsection{Process and Phases of Social Work with Children Experiencing Domestic Violence}

In case of domestic violence committed on a child, in terms of social work, detection of violence is very important. This phase should be followed by a diagnostics of the case on which an inter-disciplinary team of workers shall participate. A role of a social worker is to carry out social intervention and therapy, of course with the participation of experts from other fields, and then to take care not only of the victim of domestic violence, but also of the whole family, or the ones who are concerned.

\subsection{Detection of Domestic Violence}

Detection means revealing of domestic violence committed on a child and it is the first step in solving such issue. Vlčková (2001) describes it as a complex activity of inter-disciplinary team of workers that examine circumstances of reported or detected case of violence committed on the child. The first contact with the child suffering domestic violence is very important. Therefore, the workers who are in contact with the potential victims should be trained in identification of separate signs of domestic violence and should know procedures how to react in this kind of issue (Erdélyiová, 2001).

In particular, it applies to doctors-pediatricians (Kliegman et al., 2007), because they are the ones who should ensure collection of all materials related to health condition of the child, record and photographically document not only injuries, but also basic facts about age, development, motor skills and clothing of the child. Subsequently, they should contact a social worker who evaluates the situation and prepares an emergency plan. In USA, children's hospitals have their own teams of experts trained in detection of violence, reporting and provision of necessary help. Such team consists of pediatricians, nurses, social workers and psychologists.

Another factor that affects solution of cases of violence is reporting inhibitors. According to Dunovský et al. (1995), such inhibitors may be a lack of confidence in social care authorities, in bodies involved in criminal proceedings and disappointment with results of previous notification. Another important particle is a teacher, school and an educational facility. Registered violence committed on children is mostly announced by teachers, who report such violence to a competent office of Labour, Social Affairs and Family, Department of Social Protection and Social Guardianship. In practice, prevention against violence formation and its demonstrations (bullying, cyber-bulling, ...) are mostly carried on by schools. It is necessary to cooperate at all levels on different positions (auxiliary professions) in a fight against violence.

Another factor that affects solution of cases of violence is reporting inhibitors. According to Dunovský et al. 
(1995), such inhibitors may be a lack of confidence in social care authorities, in bodies involved in criminal proceedings and disappointment with results of previous notification. Facilitators may be involvement and preoccupation of the worker and his/her professional readiness. Laics may be doubtful; they are not sure whether the signals they hear or see are really demonstrations of violence. Moreover, they often do not know where to go and who to contact. Another factor is a fear of possible revenge of perpetrators of disclosed violence.

\subsection{Diagnostics}

Diagnostics, as the next phase of the process of solving the issue of domestic violence committed on the child is described (Dunovský et al., 1995) as a complex activity of an inter-disciplinary team detecting and reviewing all circumstances of mistreatment of the child. Social diagnosis is based on social history. It reviews current state of the child; it records deviations, social situation, relations towards the surrounding, environment, where the child lives and his/her ability to engage into social life. Moreover, it also reviews structure of the family, its stability, personality of parents and other members of the family, interest of parents in child and his/her upbringing and care.

Position and role of the social worker in compilation of the social diagnosis is unsubstitutable. During the process of compilation, the social worker uses the following methods: diagnostic interview, diagnostic observation, visit of the family, where he/she monitors housing standards, equipage and ways of mutual communication (Vlčková, 2001). Another important field is also a coordination of work of persons and authorities that cooperate during processing of anamnesis, diagnosis and therapy.

Matoušek et al. (2003) explains mapping of situation of the child by genogram and eco-map that are compiled from collected anamnestic data. Genogram displays family relationships in graphical way, and so enables to record connections and events in the form of symbols or characters. Eco-map depicts social environment of the child, family and related eco-systems.

The social worker should examine fulfillment of biological and psychological needs of the child, as well as the social environment, where the child lives. This may be done by various auxiliary models that are described

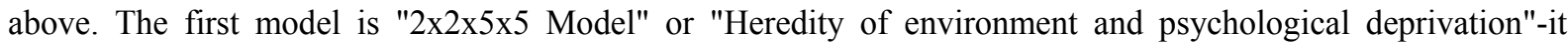
reviews both internal (heredity) and external (surrounding) influences, what represents the first number 2. Biological and psychological needs are included in the second number 2. Number 5 represents positions and roles of the child-sibling roles, roles connected with relations towards kinship, friends and peers and other persons who are important for the child. The last number 5 represents factors of legal and bio-physical nature, development factors, as well as social and situation factors (Matoušek et al., 2003).

Another model is "3x3x3 Model"-"three levels of learning, three basic social circles and three sources of risks". These are levels of learning at the level of social and emotional relations, at the level of examples and models and at the level of knowledge and information. Basic social circle includes family, school and peers of the child. Three sources of risk are represented by risk adults, risk children and risk situations. The social worker and his/her team should be able to identify and review these sources (Matoušek et al., 2003).

\subsection{Social Intervention and Therapy}

The phase of diagnostics is followed by a phase of solving the case of domestic violence. This phase includes execution of social intervention and therapy-auxiliary and protective measures in favor of the child.

An ideal solution of domestic violence committed on the child is effective intervention-it is a sophisticated dealing with the case, where the team works both with the child and adults, and one social worker is a coordinator of all interventions (Matoušek et al., 2005). Beside long-term social intervention, it is also possible to use so called single intervention, which effectiveness may be similar, if the social worker provides the client with relevant information, answers all questions of the client, invites the client to come to his/her workplace or recommends the client services of other expert (Dunovský et al., 1995).

Many researches have been devoted to violence against children. They particularly monitored frequency of separate types of violence or awareness of public about this issue. However, we focused on mapping of specific working procedures and methods of social work with children that are subjects of domestic violence and are on the edge of the researches.

\section{Research Objectives, Methods and File}

\subsection{Objectives of the Research}

The main objective of the research was to specify selected procedures and methods of the social work used in case of children who are subjects of domestic violence, as well as some circumstances and factors. We also 
concentrated our attention on identification of methods and forms of work that are used by the social workers on the Department of social and legal protection of children and social curatorship, in a crisis centre and children's home. Herein we present partial results related to some methods of the social work with children that are or were victims of domestic violence and their comparison with the methods that the social workers use on the Department of social and legal protection of children and social curatorship, in the crisis centre and the children's home.

Due to the theme we chosen to monitor, we carried out exploration research from December 2009 to February 2010. Since we did not base our research on blanket generalization of data, this fact should be taken into account in interpretation of obtained results.

\subsection{Methods of the Research}

A design of a research is qualitative-quantitative. We used methods of questionnaire and content analysis within the quantitative methodology. The questionnaire consists of 38 questions; 8 questions concentrated of identification data, 24 questions were scaled and 6 questions were opened with a possibility to write down a free answer.

We used the content analysis for evaluation of two specific cases of violence against children. We carried out its first stage. One case was solved on the Department of social and legal protection of children and curatorship and the second case was solved in the crisis centre. We monitored both cases from their announcement up to completion of work-it means a complex procedure of social work during the entire case.

We collected the data required by the questionnaires either personally on respective departments or via e-mail. All materials connected with the content analysis were provided by the Department of social and legal protection of children and curatorship and the crisis centre.

Results we obtained by the questionnaires were evaluated by Chi-squared and Kruskal-Wallis tests. We used a method of semi-structured interview within the qualitative methodology, which was evaluated by a method of open coding within this methodology.

\subsection{Research File}

The basic criterion for selection of a research file was realization of social work profession with focus on social work with children that experience domestic violence. As far as we monitored a specific sample-social workers working with children that were or are victims of domestic violence, we had only limited possibilities. Therefore, the research file consisted of 29 social workers from the Department of social and legal protection of children and curatorship, from crisis centers and children's homes in Nitra region. The return of the questionnaires was low-only $32 \%$; just 29 of 90 questionnaires were returned to us. 4 facilities informed us that they cannot provide us any information, as far as they mostly work with abused mothers. These were further processed statistically (social workers who are actively engaged in the social profession). The respondents were represented by regarding the sex-the research file consisted of 26 women and 3 men.

Regarding the place of social work execution, $59 \%$ of respondents were from Department of social and legal protection of children and curatorship, $24 \%$ were from the crisis centre and $17 \%$ were from the children's home.

We were also interested in length the participants of the research work at the respective workplaces. Employees of the Department of social and legal protection of children and curatorship have the highest number of worked years-9.6 on average. Employees of children's homes work in these institutions for 7.2 years on average and employees of the crisis centre-2.6 years. Further data are provided in the table 1.

Table 1. Number of worked years

\begin{tabular}{lllll}
\hline & OSPODaSK & KS & DeD & In total \\
\hline Number of worked months & 1962 & 220 & 432 & 2614 \\
Relative frequency in\% & 75.1 & 8.4 & 16.5 & 100 \\
Arithmetic average of worked months & 115.4 & 31.5 & 86.4 & 90.1 \\
Number of worked years & 163.5 & 18.3 & 36 & 217.8 \\
Arithmetic average of worked years & 9.6 & 2.6 & 7.2 & 7.5 \\
\hline
\end{tabular}


The abbreviation OSPODaSK is used for the answers of the employees of the Department of social and legal protection of children and social curatorship, the abbreviation KS is used for the employees of the crisis centre and the abbreviation DeD is used for the employees of the children's home.

\subsection{Results of the Quantity Research}

\subsubsection{Number of Cases of Violence against a Child at the Current Workplace}

As the first result from obtained data we would like to present number of cases of violence against children that have been reported to current workplace. The social workers have experienced many cases of violence during their work in respective facilities. We wanted to know their precise number. The employees of the crisis centre have experienced the greatest average number of cases per a person-28. Other results are presented in the table 2.

Table 2. Number of cases of violence against a child at the current workplace

\begin{tabular}{lllll}
\hline & OSPODaSK & KS & DeD & In total \\
\hline Total number of cases & 128 & 196 & 31 & 355 \\
$\%$ & 36.1 & 55.2 & 8.7 & 100 \\
Average number of cases per person & 7.5 & 28 & 6.2 & 12.2 \\
\hline
\end{tabular}

2.4.2 Methods and Procedures of the Social Work in Solving the Cases of Domestic Violence Committed on Children

The table 3 presents results per item related to use of anamnestic collection of data about the child. $62 \%$ of respondents fully agreed and $31 \%$ partially agreed with the statement that they use anamnestic collection of data. $11.8 \%$ fully disagreed with this statement-they were only the employees of OSPODaSK.

We examined whether there is statistically significant difference between the answers in use of anamnestic data collection in detection of a case of domestic violence committed on a child in terms of separate facilities. On the basis of results obtained by Kruskal-Wallis test we found out that $\mathrm{H}=2.406$ and $\mathrm{p}=0.300$ what means that there is not statistically significant difference between the groups.

Table 3. Use of anamnestic collection of data about a child

\begin{tabular}{lllllllll}
\hline & \multicolumn{2}{l}{ OSPODaSK } & KS & \multicolumn{3}{c}{ DeD } & \multicolumn{3}{c}{ In total } \\
& $\mathrm{N}$ & $\%$ & $\mathrm{~N}$ & $\%$ & $\mathrm{~N}$ & $\%$ & $\mathrm{~N}$ & $\%$ \\
\hline Fully agree & 9 & 52.9 & 6 & 85.7 & 3 & 60 & 18 & 62.1 \\
Partially agree & 6 & 35.3 & 1 & 14.3 & 2 & 40 & 9 & 31 \\
I equally agree & 0 & 0 & 0 & 0 & 0 & 0 & 0 & 0 \\
Partially disagree & 0 & 0 & 0 & 0 & 0 & 0 & 0 & 0 \\
Fully disagree & 2 & 11.8 & 0 & 0 & 0 & 0 & 2 & 6.9 \\
In total & 17 & 100 & 7 & 100 & 5 & 100 & 29 & 100 \\
Mean Rank & 16.50 & & 11.43 & & 14.90 & & & \\
\hline
\end{tabular}

We also examined methods used in preparation of diagnosis. $40.6 \%$ of respondents use diagnostic interview, $30.4 \%$ use social street work and $29 \%$ of respondents use diagnostic observation. OSPODaSK employees use diagnostic interviews most often, then in $36.6 \%$ they use the social street work and in $24.4 \%$ they use observation. KS employees use interviews and observations equally, while the social street work is used only in $6.6 \%$. DK employees use interview and social street work equally in $38.5 \%$ and the observation of client's behavior is used in $23 \%$. The results are presented in the table 4 .

Calculated value of Chi-squared $=27.37941$ is higher than table value which is 15.5 for the level of importance 0.05 . On the basis of this result we can declare that there is statistically significant difference in answers of respondents about use of separate diagnostics methods. 
Table 4. Methods used in the preparation of diagnosis

\begin{tabular}{lllllllll}
\hline & \multicolumn{2}{l}{ OSPODaSK } & KS & \multicolumn{3}{c}{ DeD } & \multicolumn{3}{c}{ In total } \\
\hline & $\mathrm{N}$ & $\%$ & $\mathrm{~N}$ & $\%$ & $\mathrm{~N}$ & $\%$ & $\mathrm{~N}$ & $\%$ \\
1-Diagnostic interview & 16 & 39 & 7 & 46.7 & 5 & 38.5 & 28 & 40.6 \\
2-Diagnostic observation & 10 & 24.4 & 7 & 46.7 & 3 & 23 & 20 & 29 \\
3-Social street work & 15 & 36.6 & 1 & 6.6 & 5 & 38.5 & 21 & 30.4 \\
In total & 41 & 100 & 15 & 100 & 13 & 100 & 69 & 100 \\
\hline
\end{tabular}

Preparation of diagnostics consists of several steps and survey of data that are the basis for initiation of intervention and therapy. We were interested in factors on which the employees of separate facilities focus during preparation of the diagnosis. These factors are described in the table 5. In $20.8 \%$ the respondents focus on relations in the family and only in 5\% they concentrate on complex evaluation of macrosystem and microsystem of the child. In $23.9 \%$, the employees of OSPODaSK monitor relationships in the family, the same percentage- 18.3 is devoted to deviations in behavior and monitoring of social situation. $16.7 \%$ of KS employees focus on deviations in behavior, social situation and relationships within the family. In DeD, in $19.2 \%$ the employees monitor deviations and relationships in the family; in $15.4 \%$ they focus on examination of biological and mental needs what presents the highest percentage of all three types of facilities.

The value of Chi-squared is 46.06532 and it is higher than the table value 31.4 for $p=0.05$. Therefore, we can state that there is statistically significant difference in answers related to preparation of the diagnosis regarding the facts the social workers in separate facilities need to find out.

Table 5. Facts necessary for preparation of the diagnosis

\begin{tabular}{lllllllll}
\hline & \multicolumn{2}{c}{ OSPODaSK } & \multicolumn{2}{l}{ KS } & \multicolumn{3}{c}{ DeD } & \multicolumn{3}{c}{ In total } \\
& $\mathrm{N}$ & $\%$ & $\mathrm{~N}$ & $\%$ & $\mathrm{~N}$ & $\%$ & $\mathrm{~N}$ & $\%$ \\
\hline 1-deviations in behavior of the child & 13 & 18.3 & 7 & 16.7 & 5 & 19.2 & 25 & 18 \\
2-social situation of the child & 13 & 18.3 & 7 & 16.7 & 4 & 15.4 & 24 & 17.2 \\
3-relationships in the family & 17 & 23.9 & 7 & 16.7 & 5 & 19.2 & 29 & 20.8 \\
4-structure of the family & 9 & 12.7 & 6 & 14.3 & 3 & 11.5 & 18 & 13 \\
5-fulfillment of biological needs & 9 & 12.7 & 5 & 11.9 & 4 & 15.4 & 18 & 13 \\
6-fulfillment of mental needs & 8 & 11.3 & 6 & 14.3 & 4 & 15.4 & 18 & 13 \\
7-examination of microsystem and macrosystem & 2 & 2.8 & 4 & 9.4 & 1 & 3.9 & 7 & 5 \\
In total & 71 & 100 & 42 & 100 & 26 & 100 & 139 & 100 \\
\hline
\end{tabular}

Preparation of the diagnosis is followed by another phase-phase of intervention. Our aim was to find out which forms of interventions are used most often by the social workers in separate facilities. The results are in the table no. 6-Single vs. long-term intervention. The long-term intervention is used in $93.1 \%$. Single intervention is used in $11.8 \%$ only by employees of OSPODaSK.

As far as after calculation of the Chi-squared $=1.516$, the value $p=0.469$ is higher than 0.05 , the difference between the answers on question about using of single or long-term intervention is not statistically significant.

Table 6. Single vs. long-term intervention

\begin{tabular}{lcccccccc}
\hline & \multicolumn{2}{c}{ OSPODaSK } & KS & \multicolumn{3}{c}{ DeD } & \multicolumn{3}{c}{ In total } \\
& $\mathrm{N}$ & $\%$ & $\mathrm{~N}$ & $\%$ & $\mathrm{~N}$ & $\%$ & $\mathrm{~N}$ & $\%$ \\
\hline $\begin{array}{l}\text { single } \\
\text { intervention }\end{array}$ & 2 & 11.8 & 0 & 0 & 0 & 0 & 2 & 6.9 \\
$\begin{array}{l}\text { Long-term } \\
\text { intervention }\end{array}$ & 15 & 88.2 & 7 & 100 & 5 & 100 & 27 & 93.1 \\
\begin{tabular}{l} 
In total \\
\hline
\end{tabular} & 17 & 100 & 7 & 100 & 5 & 100 & 29 & 100 \\
\hline
\end{tabular}


The table 7 presents particular measures used within the intervention by separate facilities and extent of their usage. The most common answer is the social street work that is used in $25.8 \%$. The next measures like examination of upbringing and nutrition and representation of a minor child at the court are in the same percentage. The least used measure within the intervention is placing of the child to the half-way house. OSPODaSK employees use the social street work in $27.5 \%$. In $50 \%$, KS employees focus on upbringing and nutrition; they do not use measures as representation of the minor child at the court and his/her placing into institutional care. DeD employees use the social street work in $33.3 \%$ and representation of the minor child in $26.7 \%$. They do not use order of educational measures.

On the basis of calculation of Chi-squared $=89.2$, which value is higher than the table value 27.6 for $p=0.05$, we can state that there is statistically significant difference between the researched groups regarding the answers on use of separate measures within the intervention.

Table 7. Measures within the intervention

\begin{tabular}{lllllllll}
\hline & \multicolumn{2}{l}{ OSPODaSK } & KS & \multicolumn{3}{c}{ DeD } & \multicolumn{3}{c}{ In total } \\
& $\mathrm{N}$ & $\%$ & $\mathrm{~N}$ & $\%$ & $\mathrm{~N}$ & $\%$ & $\mathrm{~N}$ & $\%$ \\
\hline 1-Social street work & 17 & 27.5 & 1 & 8.3 & 5 & 33.3 & 23 & 25.8 \\
2-order of educational measures & 10 & 16.1 & 4 & 33.4 & 0 & 0 & 14 & 15.7 \\
3-order of institutional care & 8 & 12.9 & 0 & 0 & 2 & 13.3 & 10 & 11.2 \\
4-placing into the half-way house & 2 & 3.2 & 1 & 8.3 & 1 & 6.7 & 4 & 4.5 \\
5-examination of upbringing and nutrition & 10 & 16.1 & 6 & 50 & 3 & 20 & 19 & 21.4 \\
6-representation of the minor child at court & 15 & 24.2 & 0 & 0 & 4 & 26.7 & 19 & 21.4 \\
In total & 62 & 100 & 12 & 100 & 15 & 100 & 89 & 100 \\
\hline
\end{tabular}

Regarding the intervention, we focused on which of above mentioned measures are used most often by the employees. In $34.5 \%$ it is the social street work; in 31\% it is representation of the minor child at the court and in $17.3 \%$ it is examination of upbringing and nutrition. Only $3.4 \%$ of employees use placing the child into the half-way house. OSPODaSK employees use the social street work most often-in 47.1\%. KS employees often use order of educational measures and examination of upbringing and nutrition. Participants of the research employed in DeD represent the minor child at the court most often.

Results of Chi-squared $=16.213, \mathrm{p}=0.039$ indicate that there is statistically significant difference in the answers of the respondents regarding the measures they use most often.

Table 8. Measures that are most often used within the intervention

\begin{tabular}{lllllllll}
\hline & \multicolumn{2}{c}{ OSPODaSK } & \multicolumn{2}{l}{ KS } & \multicolumn{2}{c}{ DeD } & \multicolumn{3}{c}{ In total } \\
& $\mathrm{N}$ & $\%$ & $\mathrm{~N}$ & $\%$ & $\mathrm{~N}$ & $\%$ & $\mathrm{~N}$ & $\%$ \\
\hline 1-Social street work & 8 & 47.1 & 1 & 14.2 & 1 & 20 & 10 & 34.5 \\
2-order of educational measures & 0 & 0 & 3 & 42.9 & 1 & 20 & 4 & 13.8 \\
3-placing into the half-way house & 1 & 5.9 & 0 & 0 & 0 & 0 & 1 & 3.4 \\
4-examination of upbringing and nutrition & 1 & 5.9 & 3 & 42.9 & 1 & 20 & 5 & 17.3 \\
5-representation of the minor child at court & 7 & 41.1 & 0 & 0 & 2 & 40 & 9 & 31 \\
In total & 17 & 100 & 7 & 100 & 5 & 100 & 29 & 100 \\
\hline
\end{tabular}

When solving cases of violence against a child, within the crisis intervention, the employees always have to decide on placing the child to institutional care or crisis centre. Therefore, we wanted to know how the social workers in separate facilities perceive this situation. Which form do they consider as more suitable? $60 \%$ of respondents prefer services of the crisis centre and $27 \%$ of them prefer institutional care. In $76.5 \%$ of cases, employees of OSPODaSK use crisis centers, in 17\% they use institutional care and in $5.9 \%$ they use half-way houses. 
Results of Chi-squared $=17.315, \mathrm{p}=0.002$ present that there is statistically significant difference between the answers of separate groups of respondents regarding the answer on using of intervention in acute cases.

Table 9. Intervention in acute cases

\begin{tabular}{lllllllll}
\hline & \multicolumn{2}{c}{ OSPODaSK } & KS & \multicolumn{3}{c}{ DeD } & \multicolumn{3}{c}{ In total } \\
& $\mathrm{N}$ & $\%$ & $\mathrm{~N}$ & $\%$ & $\mathrm{~N}$ & $\%$ & $\mathrm{~N}$ & $\%$ \\
\hline 1-crisis centre & 13 & 76.5 & 7 & 100 & 0 & 0 & 20 & 69 \\
2-half-way house & 1 & 5.9 & 0 & 0 & 0 & 0 & 1 & 3.4 \\
3-order of institutional care & 3 & 17.6 & 0 & 0 & 5 & 100 & 8 & 27.6 \\
In total & 17 & 100 & 7 & 100 & 5 & 100 & 29 & 100 \\
\hline
\end{tabular}

However, solution within the crisis intervention should be just temporary. We were interested, whether this solution is perceived by the social workers in practice similarly as we perceive it, it means whether they reconstruct the families or keep the child in institutional care or crisis centre. Their answers are presented in the table 10-Intervention-use of institutional care/crisis centre and reconstruction of the family. $82.4 \%$ of employees of OSPODaSK use reconstruction of the family and only $17.6 \%$ use institutional care or crisis centre. Employees of KS and DeD prefer reconstruction of families.

The value of Chi-squared is 2.362 and the value of $p$ is 0.307 , and so there is not statistically significant difference between the monitored groups in their use of institutional care and reconstruction of the family.

Table 10. Intervention-use of institutional care/crisis centre and reconstruction of the family

\begin{tabular}{lllllllll}
\hline & \multicolumn{2}{c}{ OSPODaSK } & KS & \multicolumn{3}{c}{ DeD } & \multicolumn{3}{c}{ In total } \\
& $\mathrm{N}$ & $\%$ & $\mathrm{~N}$ & $\%$ & $\mathrm{~N}$ & $\%$ & $\mathrm{~N}$ & $\%$ \\
\hline $\begin{array}{l}\text { Placing to institutional care/ } \\
\text { Crisis centre }\end{array}$ & 3 & 17.6 & 0 & 0 & 0 & 0 & 3 & 10.3 \\
Reconstruction of the family & 14 & 82.4 & 7 & 100 & 5 & 100 & 26 & 89.7 \\
In total & 17 & 100 & 7 & 100 & 5 & 100 & 29 & 100 \\
\hline
\end{tabular}

In our next question, which is described in table 11, we asked on opinions of the social workers regarding suitability of institutional care or reconstruction of the family. $64.7 \%$ of the employees of OSPODaSK consider reconstruction of the family as more suitable solution than institutional care. $29.4 \%$ of the employees consider both solutions as equally suitable. $57.1 \%$ of employees of KS consider reconstruction of the family as more suitable, and $42.9 \%$ consider both solutions as equally suitable. Regarding the employees of DeD, $60 \%$ of them prefer reconstruction of the family, $20 \%$ prefer institutional care and $20 \%$ consider both methods as suitable.

The results of Kruskal-Wallis test, where $\mathrm{H}=1.576, \mathrm{p}=0.455$ did not confirm statistically significant difference between monitored groups regarding the question of preferring of the institutional care or reconstruction of the family.

Table 11. Institutional care and reconstruction of the family

\begin{tabular}{lllllllll}
\hline & \multicolumn{2}{c}{ OSPODaSK } & KS & \multicolumn{3}{c}{ DeD } & \multicolumn{3}{c}{ In total } \\
& $\mathrm{N}$ & $\%$ & $\mathrm{~N}$ & $\%$ & $\mathrm{~N}$ & $\%$ & $\mathrm{~N}$ & $\%$ \\
\hline Institutional care is more suitable & 0 & 0 & 0 & 0 & 1 & 20 & 1 & 3.5 \\
Reconstruction of the family is more suitable & 11 & 64.7 & 4 & 57.1 & 3 & 60 & 18 & 62 \\
I cannot judge & 1 & 5.9 & 0 & 0 & 0 & 0 & 1 & 3.5 \\
Both are equally suitable & 5 & 29.4 & 3 & 42.9 & 1 & 20 & 9 & 31 \\
In total & 17 & 100 & 7 & 100 & 5 & 100 & 29 & 100 \\
Mean rank & 15.32 & & 16.71 & & 11.5 & & & \\
\hline
\end{tabular}


The table 12 presents results related to procedures used within the therapy from the perspective of monitored groups. In $35.6 \%$ cases, the employees of OSPODaSK use reconstruction of the families and only in $2.2 \%$ cases they use therapy with the victim. In $38.9 \%$, the employees of KS use advisory dialogue and they do not use a therapy with the abuser. In $35.7 \%$, the employees of $\mathrm{DeD}$ use advisory dialogue and they also do not use a therapy with the abuser. Regarding the therapy, in $35.1 \%$ of cases the socials workers use advisory dialogue as one of the most commonly used method, while only in $2.6 \%$ of cases they use a therapy with the abuser.

The table value is 23.7 and it is smaller than the calculated Chi-squared, which is 72.5 at the $14^{\text {th }}$ level of importance. There is statistically significant difference between the answers of monitored groups regarding the use of separate procedures within the therapy.

Table 12. Procedures within the therapy

\begin{tabular}{lllllllll}
\hline & \multicolumn{2}{c}{ OSPODaSK } & \multicolumn{2}{c}{ KS } & \multicolumn{3}{c}{ DeD } & \multicolumn{3}{c}{ In total } \\
& $\mathrm{N}$ & $\%$ & $\mathrm{~N}$ & $\%$ & $\mathrm{~N}$ & $\%$ & $\mathrm{~N}$ & $\%$ \\
\hline 1-setting of a child at ease & 11 & 24.4 & 6 & 33.3 & 4 & 28.6 & 21 & 27.3 \\
and instruction of the child on his/her rights & & & & & & & & \\
2-advisory dialogue & 15 & 33.3 & 7 & 38.9 & 5 & 35.7 & 27 & 35.1 \\
3-reconstruction of the family & 16 & 35.6 & 4 & 22.2 & 4 & 28.6 & 24 & 31.1 \\
4-therapy with the victim & 1 & 2.2 & 1 & 5.6 & 1 & 7.1 & 3 & 3.9 \\
5-therapy with the abuser & 2 & 4.5 & 0 & 0 & 0 & 0 & 2 & 2.6 \\
In total & 45 & 100 & 18 & 100 & 14 & 100 & 77 & 100 \\
\hline
\end{tabular}

We also concentrate our attention on detection of use of an individual plan for solving of the crisis. We found out that the employees of OSPODaSK use the individual plan for solving of the crisis in $58.8 \%$ they fully agree with using of this plan and in $11.8 \%$ only partially, while in case of KS, $100 \%$ of respondents fully agree with using of the individual plan. In case of DeD, $80 \%$ of respondents fully agree with its using. The total percentage of full use of the individual plan for solving of the crisis is $72.5 \%$.

By results of Kruskal-Wallis test, where the value $\mathrm{H}=3.799$ and $\mathrm{p}=0.150$ we found out that there is not statistically significant difference between the monitored groups regarding using or not using of the individual plan for solving the crisis.

Table 13. Use of the individual plant for solving the crisis with a real client

\begin{tabular}{lllllllll}
\hline & \multicolumn{2}{l}{ OSPODaSK } & KS & \multicolumn{3}{c}{ DeD } & \multicolumn{3}{c}{ In total } \\
& $\mathrm{N}$ & $\%$ & $\mathrm{~N}$ & $\%$ & $\mathrm{~N}$ & $\%$ & $\mathrm{~N}$ & $\%$ \\
\hline Fully agree & 10 & 58.8 & 7 & 100 & 4 & 80 & 21 & 72.5 \\
Partially agree & 2 & 11.8 & 0 & 0 & 0 & 0 & 2 & 6.9 \\
I equally agree and disagree & 0 & 0 & 0 & 0 & 0 & 0 & 0 & 0 \\
Partially disagree & 3 & 17.6 & 0 & 0 & 0 & 0 & 3 & 10.3 \\
Fully disagree & 2 & 11.8 & 0 & 0 & 1 & 20 & 3 & 10.3 \\
In total & 17 & 100 & 7 & 100 & 5 & 100 & 29 & 100 \\
Mean rank & 16.82 & & 11 & & 14.4 & & & \\
\hline
\end{tabular}

Specific procedures of the social work used by the social workers are specified in the table 14. As far as the question was opened, we describe separate categories of answers of the respondents according to their frequency. They are arranged from the most commonly used answers to the ones that were not used so often. The most commonly used procedure in all facilities is the diagnostic interview with a child. This procedure is also most commonly used by individual social workers employed in OSPODaSK, KS and DeD. Document analysis is a procedure that is used at least. 
Table 14. Specific procedures of work that are most often used when solving an issue of domestic violence against a child

\begin{tabular}{lllll}
\hline Categories & OSPODaSK & KS & DeD & In total \\
\hline Diagnostic interview with a child & 10 & 4 & 7 & 21 \\
Play therapy, playing of roles, children communities & 1 & 3 & 5 & 9 \\
Diagnostic observation & 5 & 0 & 4 & 9 \\
Communication with a court/DeD/KS/school/police force & 8 & 0 & 0 & 8 \\
Social street work & 5 & 0 & 0 & 5 \\
Work with family/surrounding & 4 & 0 & 1 & 5 \\
Work on anamnesis & 4 & 0 & 1 & 5 \\
Educational measures & 1 & 0 & 3 & 4 \\
Visit of pediatrician & 2 & 1 & 0 & 3 \\
Representation of the minor child at court & 2 & 0 & 0 & 2 \\
Isolation from an aggressor & 0 & 1 & 1 & 2 \\
Placing to the crisis centre & 1 & 0 & 1 & 2 \\
Individual plan of work & 2 & 0 & 0 & 2 \\
Document analysis & 0 & 0 & 1 & 1 \\
In total & 45 & 9 & 24 & 78 \\
\hline
\end{tabular}

We tried to identify obstacles at work by opened questions. The answers to these questions are provided in the table 15. On one side the same number of respondents do not see any obstacles at work, however on the other hand they indicate an obstacle due to confusion of competencies. According to the employees of OSPODaSK the biggest obstacle is the amount of administrative work they have to do and so they do not have enough time for clients. Regarding KS and DeD, the biggest problem is ambiguity of social worker's competences.

Table 15. Obstacles in execution of the social work profession

\begin{tabular}{lllll}
\hline Categories & OSPODaSK & KS & DeD & In total \\
\hline I do not see any obstacles & 4 & 0 & 3 & 7 \\
Ambiguity of competences & 1 & 3 & 3 & 7 \\
A lot of administrative work-little time for clients & 4 & 0 & 0 & 4 \\
Small number of employees & 3 & 0 & 0 & 3 \\
Lack of time & 2 & 0 & 0 & 2 \\
Insufficient legislation & 0 & 1 & 1 & 2 \\
The family does not cooperate & 1 & 1 & 0 & 2 \\
Insufficient protection of a person & 2 & 0 & 0 & 2 \\
In total & 17 & 5 & 7 & 29 \\
\hline
\end{tabular}

The table 16 presents findings on monitoring of cases of violence against children also after the phase of intervention is finished, as this need is often emphasized by theoretical approaches. In $52.9 \%$, the respondents employed in OSPODaSK fully agreed with the statement, that they monitor the family also after the intervention is finished. $35.3 \%$ of respondents partially agree. In case of employees of KS, $14.3 \%$ fully agree and $71.4 \%$ partially agree. In case of $\mathrm{DeD}, 40 \%$ of respondents partially agreed and $40 \%$ of them fully agreed with the statement that they monitor the family also after the case is closed.

By results of Kruskal-Wallis test, where $\mathrm{H}=8.177$ and $\mathrm{p}=0.017$, we found out that there is statistically significant difference between the monitored groups regarding the question of monitoring of the family after the case is closed. 
Table 16. Monitoring of the family after the case is closed

\begin{tabular}{lllllllll}
\hline & \multicolumn{2}{l}{ OSPODaSK } & KS & \multicolumn{3}{c}{ DeD } & \multicolumn{3}{c}{ In total } \\
& $\mathrm{N}$ & $\%$ & $\mathrm{~N}$ & $\%$ & $\mathrm{~N}$ & $\%$ & $\mathrm{~N}$ & $\%$ \\
\hline 1-fully agree & 9 & 52.9 & 1 & 14.3 & 0 & 0 & 10 & 34.5 \\
2-partially agree & 6 & 35.3 & 5 & 71.4 & 2 & 40 & 13 & 44.9 \\
3-I equally agree and disagree & 0 & 0 & 0 & 0 & 0 & 0 & 0 & 0 \\
4-partially disagree & 2 & 11.8 & 0 & 0 & 1 & 20 & 3 & 10.3 \\
5-fully disagree & 0 & 0 & 1 & 14.3 & 2 & 40 & 3 & 10.3 \\
In total & 17 & 100 & 7 & 100 & 5 & 100 & 29 & 100 \\
Mean rank & 11.85 & & 16.93 & & 23 & & & \\
\hline
\end{tabular}

The table 17 presents percentage of responses related to provision of legal advice to a victim and parents. Legal advice to the victim is fully used in $37.9 \%$ of cases and partially in $27.6 \%$ of cases. This kind of advice is not used in $27.6 \%$ of cases. Legal advice is mostly provided by the employees of OSPODaSK- $58.8 \%$, while only $57.1 \%$ of employees of KS use this method.

On the basis of the results, where $\mathrm{H}=9.710$ and $\mathrm{p}=0.008$ it is possible to state that there is statistically significant difference between the monitored groups related to answers on provision of legal advice also after finishing of the intervention.

Table 17. Legal advice to victim and parents who do not abuse their children after finishing of the intervention

\begin{tabular}{lllllllll}
\hline & \multicolumn{2}{l}{ OSPODaSK } & KS & \multicolumn{3}{c}{ DeD } & \multicolumn{3}{c}{ In total } \\
& $\mathrm{N}$ & $\%$ & $\mathrm{~N}$ & $\%$ & $\mathrm{~N}$ & $\%$ & $\mathrm{~N}$ & $\%$ \\
\hline 1-fully agree & 10 & 58.8 & 1 & 14.3 & 0 & 0 & 11 & 37.9 \\
2-partially agree & 5 & 29.4 & 2 & 28.6 & 1 & 20 & 8 & 27.6 \\
3-I equally agree and disagree & 0 & 0 & 0 & 0 & 0 & 0 & 0 & 0 \\
4-partially disagree & 0 & 0 & 0 & 0 & 2 & 40 & 2 & 6.9 \\
5-fully disagree & 2 & 11.8 & 4 & 57.1 & 2 & 40 & 8 & 27.6 \\
In total & 17 & 100 & 7 & 100 & 5 & 100 & 29 & 100 \\
Mean rank & 11.09 & & 19.86 & & 21,5 & & & \\
\hline
\end{tabular}

\subsubsection{Result of Quality Research}

The following part contains results of semi-structured interviews performed by us. The table presents a hierarchy of categories which is given by the highest frequency of segments appearing in this hierarchy.

Table 18.

\begin{tabular}{ll}
\hline $\begin{array}{l}\text { Categories and sub-categories-grouped according to frequency of segments on the } \\
\text { basis of open coding }\end{array}$ & Frequency \\
\hline Work procedure & $\mathbf{2 9}$ \\
-interview & 25 \\
-observation & 19 \\
-anamnesis & 17 \\
-social street work & 17 \\
-other measures & 11 \\
-communication with family members & 8 \\
Diagnostics & $\mathbf{2 6}$ \\
-intervention & 23 \\
\hline
\end{tabular}




\begin{tabular}{ll}
\hline $\begin{array}{l}\text { Categories and sub-categories-grouped according to frequency of segments on the } \\
\text { basis of open coding }\end{array}$ & Frequency \\
\hline -therapy & 20 \\
Reasons of children torture & $\mathbf{2 5}$ \\
-disharmony in family & 24 \\
-psychic & 21 \\
-a child himself/herself & 13 \\
Measures & $\mathbf{2 4}$ \\
-street work & 22 \\
-pleading in court & 20 \\
-assessment & 15 \\
-isolation & 2 \\
Performance barriers & $\mathbf{1 5}$ \\
-legislation & 13 \\
-shortage of possibilities & 10 \\
-administration & 9 \\
\hline
\end{tabular}

\subsubsection{The Most Impoitant Conclusions Are Listed Below}

An over view of the research findings

1) We found out statistically significant difference between separate facilities regarding the methods used for preparation of the diagnosis. We found out that the social workers in DeD use the diagnostic interview and the social street work to the same extent as the social workers in KS use diagnostic observations and dialogues. The social workers from OSPODaSK most often use diagnostic interview.

2) The monitored sample of respondents most often use long-term intervention during their work.

3) Participants prefer services of the crisis centre. On the basis of results we can state that the social workers more often use crisis centers in case of violence committed on the child.

4) $79.4 \%$ of social workers continue in monitoring of cases of violence against the child also after such cases are closed. $20.6 \%$ of social workers do not use this method. Differences between high percentage of using of monitoring by the social workers in KS and OSPODaSK and lower percentage in case of the social workers from $\mathrm{DeD}$ are statistically significant.

5) Number of cases of violence against children the social workers have experienced at their current workplace. Department of social and legal protection of children and social curatorship registers 128 cases, the crisis centre registers 196 cases and the children's home registers 31 cases.

\subsubsection{Limitations}

A research sample coming from one region may be considered as a limit of research. In regard to research file, as well as limits of used methods, the obtained research data cannot be generalized. Return of the questionnaires was low. Representatives of the facilities were not interested in participation on the research, as far as they work with vulnerable groups such as tortured women with children. It is also necessary to take into account an economic situation of the respective region, which may affect increased number of these phenomena. Finally we would like to mention a lack of research studies dealing with an issue of domestic violence against children in Nitra region. Beside these limits we suppose that the obtained findings of mixed research will be used in further research and will help to bring knowledge into practice.

\section{Conclusion and Discussion}

In spite of the fact that it is not possible to generalize the obtained data due to the research file and limits of used methods, this research bring us findings from the field that is studied only a little within the connection of social work and domestic violence. In summarization of results we have to consider that the blanket generalization of results was not our aim. A method of research chosen by us disclosed "grey places" in practical social work in 
the field of domestic violence committed on children. Qualitative research confirmed results of the questionnaire survey and pointed out barriers, with which the social workers meet during their work.

Anamnestic collection of data about a child is the most often used method and form of the social work used by asked social workers when they solve cases of domestic violence committed on children. It is a long-term process of collection of information and coordinated work of the social worker with other experts. It is performed during the phase of detection and violence diagnostics. The phase of detection is followed by the diagnostics. Within this phase, the social workers from all three monitored facilities most often use diagnostic interview. The social workers prefer long-term intervention instead of the short one. Within the intervention, they use the social street work-they work with family, school and a facility, where the child is placed. They communicate with the courts and pediatricians. They use order of educational measure, order of institutions care, examination of upbringing and nutrition and representation of the minor child at the court. Within the intervention, they most often use the social street work. In acute cases, the social workers more often use services of crisis centers. During the phase of therapy, first of all the social workers have to set the child at ease and instruct the child on his/her rights. They use advisory dialogue and individual plan in order to solve the crisis, as well as play therapy, playing of roles and children communities. The social workers working on the Department of social and legal protection of children and curatorship most often use anamnestic data collection, diagnostic interview and monitoring of relationships in families. They prefer long-term intervention despite the fact that also single intervention occurred among answers of these respondents. Within the single intervention, they use the social street work. The participants from DeD and KS as the only ones answered that they also communicate with courts, school and police, and work with the families/surrounding of the child. The social street work is followed by ordering of educational measures, ordering of institutional care and examination of upbringing and nutrition. Within the crisis intervention, the social workers prefer a crisis centre. In order to solve the crisis, the social workers use the individual plan within the therapy (however, not in such extent as social workers in other facilities) and reconstruction of the family. The social workers from OSPODaSK most often use monitoring of the family also after the case is closed, and legal advice to the victim.

According to the answers, the social workers from the crisis centre use anemnestic data collection more often than the social workers from OSPODaSK, while diagnostic interview and observation are used similarly. They also use play therapy, paying of roles and children communities. In particular, the social workers monitor deviations in behavior, social situation and relationships in the family. They prefer long-term intervention. Ordering of educational measures and examination of upbringing and nutrition is the most often used procedure of intervention. Within the therapy, to solve the crisis they use advisory dialogue and the individual plan, where they confirmed its $100 \%$ use as the only ones. They monitor the family also after finishing of the intervention, but only within catamnesis. They do not provide legal advisory services in $57 \%$ of cases.

The asked social workers working in the children' s home use anamnestic data collection similarly as their colleagues from other facilities, or even more often than their colleagues from OSPODaSK. Within the diagnostics, the most important is dialogue. They prefer long-term intervention. Within this intervention, they prefer the social street work, examination of upbringing and nutrition of the child and representation of the minor child at the court, which is the most often used form of intervention by the social workers from DeD. In acute cases, they prefer institutional care. They think that the most suitable form of long-term solution of the problem is reconstruction of the family. Within the therapy, to solve the crisis they use advisory dialogue and the individual plan. Monitoring of the family after the case is closed and legal advice are the forms that are used just very little by these social workers.

We found out statistically significant difference between separate facilities regarding the methods used for preparation of the diagnosis. We found out that the social workers in DeD use the diagnostic interview and the social street work to the same extent as the social workers in KS use diagnostic observations and dialogues. The social workers from OSPODaSK most often use diagnostic interview. We were also interested in facts, on which the social workers focus when they prepare the diagnosis. Most of the respondents answered that they focus on relationships in the family. We found that there is statistically significant difference between the answers of the monitored groups regarding the fact on which they concentrate. Based on these results we can point out that that the social workers from separate monitored facilities use different methods and procedures during their work with children. It is also necessary to take into consideration that they work with children in different phases of solving the case.

According to results we found out that the monitored sample of respondents most often use long-term intervention during their work. It means that they work with clients on a long term basis in order to solve their situation, what is crucial when dealing with cases of violence against children. In monitoring the crisis 
intervention in acute cases, we found out statistical significance in answers of separate groups. $69 \%$ of participants prefer services of the crisis centre and $27 \%$ of participants prefer institutional care. On the basis of results we can state that the social workers more often use crisis centers in case of violence committed on the child. It may be connected with the fact that in cases of domestic violence, the social workers always put the abused child into safe surrounding until a parent who committed the violence is convicted. The aim of this measure is to provide the child necessary intervention in order to improve his/her physical, but especially mental condition, and then the child can return back to a parent who did not commit violence on the child or the child is placed into foster care. Our results (that are, however, not representative) do not correspond with the results presented by Erdélyiová (2001) and Matouška et al. (2003). According to these authors, in our country, the social workers more often decide on placing the child into foster care.

We also found out that almost $89.7 \%$ of respondents prefer reconstruction of the family. $62 \%$ of total number of respondents considers the reconstruction of the family as more suitable solution than the institutional care. 3.5\% of respondents consider the institutional care as more suitable and $31 \%$ of respondents consider both solutions as suitable. Our results correspond with thesis of Šramová (2004) that the social workers use reconstruction of the family, because they try to preserve the family.

In questions of therapy, the social workers in DeD and KS mostly use advisory dialogue. This may be caused particularly by different scope of their work, as far as the social workers from OSPODaSK more often use reconstruction of the family.

$79.4 \%$ of social workers continue in monitoring of cases of violence against the child also after such cases are closed. $20.6 \%$ of social workers do not use this method. Differences between high percentage of using of monitoring by the social workers in KS and OSPODaSK and lower percentage in case of the social workers from DeD are statistically significant.

We found out number of cases of violence against children the social workers have experienced at their current workplace. Department of social and legal protection of children and social curatorship registers 128 cases, the crisis centre registers 196 cases and the children's home registers 31 cases. For comparison, Kliegman et al. (2007) mentions 3 mil. of children that were victims of domestic violence in 1995 in USA. Dunovský et al. (1995) mentions 4,200 cases in 1992 in Great Britain. According to findings of UNICEF (Public Health Authority, ... 2009), unofficial estimations are 1 to 2\%. In 1999 the association Slonad carried out a research in Slovakia with a sample of 5,230 children at the age of 15 to 16 . According to results, up to quarter of these children experienced physical abuse and $12 \%$ of them were victims of sexual abuse. If we come out from the fact that the social workers differentiate in number of years of practice in the social work (own experiences and mature personality), as well as in type and specialization of their education, it is more than obvious that they may not understand reasons of used types of intervention, particularly in choice of resources of a theoretical background, which precede the intervention (whether they are defined by culture of organization, in which the social worker is employed or his/her own decision). For this reason we consider a continual education in follow-up courses as important. Not only in order to achieve understanding between the social workers, but also to achieve embracement of reasons of choice of respective interventions by other members of inter-disciplinary teams from other professions. Ideally, these basic platforms would be supplemented by common trainings of teams, and these trainings would be primarily focused on mutual understanding of different professional "jargon", mutual introduction of risks resulting from ethical problems and dilemmas connected with performance of separate professions, and training in different forms of cooperation mainly in critical solutions.

For a social work profession and for the forms of life-long learning we also recommend historically proven practice (thirties of the 20th century), when the street work employees would participate on exchanging study programs on the departments not only in their country of work, but also abroad in order to apply social work interventions for the same target group. (Kodymová, 2010)

Nowadays, for practical social work it is absolutely necessary to continue in coordinated cooperation of experts when solving the issue of domestic violence as is clear from the previous text. Subsequently, in case of successful teams it would be necessary to establish an electronic database containing successful cases of practice, which would focus on successful interventions of the teams and their separate elements and solutions of ethical problem or dilemma situations that may accompany separate interventions.

It is also necessary to increase number of social workers working in the facilities and institutions to required level regarding the number of clients. Regarding the transitional period, we suggest that a professional social worker, and so the author of respective intervention (university education is a must), cooperates with an assistant 
(secondary education focused on helping professions is enough), who would relieve social worker from common administrative works (e.g. transcripts of hearings, coordination of meetings, searching of files, etc.).

Another important factor is unsatisfactory working background of the social workers-from a space for performance of the activity (small offices causing lack of privacy when dealing with clients), up to universal software that could help to unify a description of outputs from executed interventions and so enable basic efficiency synchronization at least on the basic level.

Last, but not least, it is a care for social workers for example in the form of benefits: longer holiday for recreation, possibility of spas, possibility of extended health care paid by insurance, or other measures.

The social workers should organize more systematic trainings for both laics and experts about the issue of domestic violence against children, e.g. in the form of workshops. They should be trained in new possible procedures, including specialized training skills for experts in this field, which would help them to perform their work more effectively, more sensitively and on higher professional level without reproducing some discriminatory and other harmful stereotypes, e.g. gender stereotypes.

It would be also necessary to use interdisciplinary cooperation and terrain work. However, it would be necessary to extend its impact within prevention, and so to ensure sufficient prevention and intervention for children and families (Markova, Ilavská, \& Juhasova, 2011, p. 136).

For primary intervention, it is very necessary to perform targeted actions that would focus on general public and children as such, e.g. in the form of lectures at schools, handing out of brochures, etc., which at least would contain important contacts, information on forms, reasons and mechanisms of violence and possibilities of help, description of steps and procedures to be used in case of violence against the child, etc.

Within the secondary prevention and covering of risk groups, the social workers should visit the risk families as it is done by social workers. From the results of the research it is evident that in our country the social workers use street work, however, it has its particularities and it concentrates on work with the family, where the violence was detected and it is being solved. It is necessary to monitor the families also after the case is closed. This may be done by visits. The street work should also be carried out in families, where the violence have not been committed yet, but the surrounding, standard of hygiene, social, relationship and health problems may form a presupposition for violence against a child. However, it is necessary to create corresponding conditions for realization of such street work. If we summarize presented measures of prevention, they show us a necessity of a social worker who is a coordinator-or an organizer of activities of interdisciplinary teams and individual professionals. Such social worker could be a social worker working in the municipality, who has all conditions for proposing of interventions in respective community on the basis of his/her knowledge of a structure of this community, its particularities, local conditions and possibilities. On the basis of holistic approach, this social worker could use methods and techniques of the social work with using a concept of networking and coordinated cooperation in order to identify a problem better and to assess a situation followed by subsequent proposal of intervention in order to achieve desired change of life of persons involved (Kodymová \& Holda, 2010; Kodymová \& Suda, 2013).

Methods and techniques of the social work should be chosen according to a problem, not to require that a problem meets a method. Many methods and procedures may be combined together what also applies in cases of socio-pathologic phenomena (Schavel \& Matel, 2011, p. 62).

\section{References}

Bodnárová, B., \& Filadelfiová, J. (2004). Status and social conditions of youth protection and monitoring respect for children's rights under the Convention on the Rights of the Child and other international instruments relating to children's rights. Secondary analysis of available statistical and research data. Retrieved from http://www.employment.gov.sk/

Čírtková, L. (2006). Domestic violence facts and paradoxes. Social work, č. 2, s. 54-67.

Collins, D., Jordan, C., \& Colema, H. (2009). An introduction in family social work (3rd ed.). Belmont: Brooks/Cole.

Couished, V., \& Orme, J. (2006). Social work practice (4th ed.). New York: Palgrave Macmillan.

Dunovský et al. (1995). Abused, neglected and abused child. Praha: Publishing Grada.

Erdélyiová, R. (2001). Strategies to combat domestic violence. Bratislava: Publishing Ministry of government Slovak republic. 
Fuchsová, K. (2008). Child abuse. Bratislava: Iris.

Haburajová-Ilavská, L. (2006). Krízové centrá ich ciel' a poslanie. In. Problematika sociálních skupin ve výuce společenskovedních předmetu, Brno: Masaryk university.

Hewitt, S. (1998). Assessing allegations of sexual abuse in preschool children. Understanding small voices. London: SAGE Publications. Child abuse and neglect. Prevention of Child Abuse and Neglect Fatalities Study Number: 9, 2008. Retrieved from http://www.childabuse.com/fs $9 . h t m$

Kliegman, R., Behrman, R., Jenson, H., \& Staton, B. (2007). Nelson Textbook of Pediatrics (18th ed.). Philadelphia: W.b. Saunders Company.

Kodymová, P. (2010). Celoživotní vzdělávání českých sociálních pracovnic-realita a ideály v roce 1935. časopis Fórum, č.1, s. 123-125.

Kodymová, P., \& Holda, D. (2010). Možnosti praxe sociální práce v kontextu rodin dětí se zdravotním postižením. časopis Fórum, č.1, s. 73-87.

Kodymová, P., \& Suda, R. (2013). Obce jako výzva pro praxi sociální práce. časopis Fórum, č.1, s.133-141.

Marková, D., Ilavska, L. H., \& Juhasova, D. (2011). Okolnosti a podmienky sociálnej práce s detmi zațivajúcimi domáce násilie. In Zborník z medzinárodnej konferencie Politiky a paradigmata sociální práce: Co jsme zdědili a co s tím uděláme? Zlín: UTB.

Mátel et al. (2011). Aplikovaná sociálna patológia v sociálnej práci. Bratislava: VŠ ZaSP sv. Alzbety.

Matoušek et al. (2003). Methods of social work. Praha: Portál.

Ondrejkovič, P. A. (2000). Sociálna patológia. Bratislava: VEDA.

Sajkowska et al. (2007). Protecting children against corporal punishment-awareness campaigns. Bratislava: Publishing Rady Európy.

Shipway, L. (2005). Domestic violence. A handbook for health professionals. New York: Routledge. Office of Public Health Slovak republic. Child abuse, 2009. Retrieved from http://www.uvzsr.sk/index.php?option=com_content\&view=article\&id=370:tyranie-deti\&catid=63:deti-a-m lade\&Itemid $=70$

Vlčková, M. (2001). Child abuse. Bratislava: Univerzity of Komensky.

\section{Copyrights}

Copyright for this article is retained by the author(s), with first publication rights granted to the journal.

This is an open-access article distributed under the terms and conditions of the Creative Commons Attribution license (http://creativecommons.org/licenses/by/3.0/). 